\author{
Asian Journal of \\ Medical and Biological Research \\ ISSN 2411-4472 (Print) 2412-5571 (Online) \\ www.ebupress.com/journal/ajmbr
}

\title{
Article \\ Physicochemical properties and plankton composition of the river Meghna, Bangladesh
}

\author{
Md. Robiul Awal Hossain ${ }^{1}$, Md. Mehedi Hasan Pramanik ${ }^{1}$, Flura $^{1}$, Md. Istiaque Haidar ${ }^{1}$ and Yahia Mahmud ${ }^{2}$ \\ ${ }^{1}$ Bangladesh Fisheries Research Institute, Riverine Station, Chandpur-3602, Bangladesh \\ ${ }^{2}$ Bangladesh Fisheries Research Institute, Head Quarter, Mymensingh-2201, Bangladesh
}

*Corresponding author: Flura, Bangladesh Fisheries Research Institute, Riverine Station, Chandpur-3602, Bangladesh.E-mail: flura_bfri@yahoo.com

Received: 07 June 2016/Accepted: 23 June 2016/ Published: 30 June 2016

\begin{abstract}
The present study was conducted to assess the physicochemical properties and plankton composition of water from the river Meghna (Shatnol to Chor Alexander) in thirteen (13) sampling spots during the period of July 2014 to June 2015. Ten (three were physical and seven were chemical) physicochemical parameters of water viz temperature (air and water), transparency, dissolved oxygen (DO), free carbon dioxide $\left(\mathrm{Co}_{2}\right)$, Conductivity, $\mathrm{pH}$, total hardness, total alkalinity and ammonia $\left(\mathrm{NH}_{3}\right)$, plankton community of both phytoplankton and zooplanktons were studied in aforesaid 13 sampling spots of the river Meghna. Maximum air temperature was recorded $37^{\circ} \mathrm{C}$ at Ananda Bazar. Maximum water temperature was recorded $30^{\circ} \mathrm{C}$ at Kaligonj, Chor Ludhua and Chor Alexander area of the river Meghna. Transparency was found minimum $12 \mathrm{~cm}$ at Chor Ludhua and maximum $75 \mathrm{~cm}$ at Horina Ghat. The concentration of dissolved oxygen was found maximum at Chor Voirabi and Horina Ghat $7.3 \mathrm{mg} / \mathrm{l}$ and was found minimum at Kaligonj $3.5 \mathrm{mg} / \mathrm{l}$. Free $\mathrm{CO}_{2}$ was found highest at Kaligonj $17 \mathrm{mg} / \mathrm{l}$ and lowest at Horina Ghat $5 \mathrm{mg} / \mathrm{l}$. pH was found ranged from almost neutral to alkaline (Minimum 7.2 to Maximum 9). Total hardness was found highest at Chor Alexander $802 \mathrm{mg} / \mathrm{l}$ and lowest at Eklaspur $35 \mathrm{mg} / \mathrm{l}$. Total alkalinity was found highest at Chor Alexander $145 \mathrm{mg} / \mathrm{l}$ and found minimum at Madrasa Ghat and Hizla $29 \mathrm{mg} / \mathrm{l}$. Conductivity was found highest at Chor Alexander and Chor Ludhua 1000 $\mu \mathrm{s} / \mathrm{cm}$. Ammonia concentration was found ranged from 0.00 to $0.03 \mathrm{mg} / \mathrm{l}$. The mean contribution of phytoplankton was about $90.5 \%$ of the total planktonic organisms and zooplankton contributed the rest. The major groups of phytoplankton were found Bacillariophyceae, Chlorophyceae, Cyanophyceae, Dinophyceae, Euglenophyceae, Myxophyceae and Xanthophyceae. Total 9 genera of zooplankton were identified from four families namely Rotifera with 2 genera, Cladocera with 3 genera, Copepoda with 3 genera and Ostracoda with 1 genus from the selected sampling spots.
\end{abstract}

Keywords: physicochemical; plankton; composition; water and the Meghna river

\section{Introduction}

Bangladesh lies in the delta of the world's three great river systems (the Ganges-Padma, the BrahmmaputraJamuna and the Meghna river system and a complex network of 230 rivers. These three mighty river basins drain a catchment area of 1,720,000 $\mathrm{km}^{2}$ of which only $7 \%$ lies in Bangladesh (UN, 1995). The confluences of Padma and Meghna and Tetulia river is a very significant water body. It plays an important role as the major nursery and breeding grounds of national fish, hilsa (Tenualosa ilisha) and many other commercially important riverine fishes (Haroon, 1998). Water maintains an ecological balance between various group of living organism and their environment (Khanna et al. 2012). The physical and chemical characteristics of water bodies affect the species composition, abundance, productivity and physiological conditions of aquatic organisms. These stressed systems support an extraordinarily high proportion of the world's biodiversity. Biological potentiality of an aquatic ecosystem depends on the biomass of the plankton. The knowledge on the abundance, composition and 
seasonal succession of the same is a prerequisite for the successful management of an aquatic ecosystem (Ahmed et al. 2003). Phytoplankton is one of the most essential characteristics of the aquatic ecosystem for maintaining its stability and a means of coping with any environmental change (Hambright and Zohary, 2000). Therefore, phytoplankton population observation may be used as a reliable tool for biomonitoring studies to assess the pollution status of aquatic bodies. Phytoplankton is the primary producers for the entire aquatic body and comprises the major portion in the ecological pyramids (Odum, 1971). In the consumer food chain of aquatic ecosystems zooplankton play an important role in the transfer of energy from the primary producer to fish. They play an important role in the natural food chain which constitute important food item of omnivorous and carnivorous fishes. Over the last few decades, there has been much interest in the processes influencing the development of phytoplankton communities, primarily in relation to physicochemical factors (Akbay et al. 1999 and Peerapornpisal et al. 1999). The algae co-occur even though each species has a specific niche based on its physiological requirements and the constraints of the environment. The present baseline information of the physicochemical properties of river water and plankton composition would be a useful tool for further ecological assessment and monitoring of the river quality.

\section{Materials and Methods}

\subsection{Study area}

The present study was carried out monthly during the year July 2014 to June 2015. Total thirteen (13) sampling stations with respective GPS point namely Madrasa Ghat (MG), Ananda Bazar (AB), Eklaspur (Ep), Shatnol (Sn), Horina Ghat (HG), Haim Chor (HC), Chor Voirabi (CV), Ishanbala (Ib) at Chandpur, Alexander (Axr), Chor Ludhua (CL) at Luximpur, Kaligonj (Kg), Hizla (Hz) at Barisal and Chor Jalalpur (CJ) at Shariatpur district were selected on the river Meghna for the collection and analysis of water and plankton samples (Table $1)$.

\section{Table 1. Name of the sampling stations with GPS point.}

\begin{tabular}{lll}
\hline Serial No. & Name & GPS Location (Latitute, Longitute) \\
\hline 1. & Madrasa Ghat (MG), Chandpur & $23014.116^{\prime} \mathrm{N}, 90038.423^{\prime} \mathrm{E}$ \\
2. & Ananda Bazar (AB), Chandpur & $23014.825^{\prime} \mathrm{N}, 90038.756^{\prime} \mathrm{E}$ \\
3. & Eklaspur (Ep), Chandpur & $23022.487^{\prime} \mathrm{N}, 90036.313^{\prime} \mathrm{E}$ \\
4. & Shatnol (Sn), Chandpur & $23027.726^{\prime} \mathrm{N}, 90035.402^{\prime} \mathrm{E}$ \\
5. & Horina Ghat (HG), Chandpur & $23009.717^{\prime} \mathrm{N}, 90038.560^{\prime} \mathrm{E}$ \\
6. & Haim Chor (HC), Chandpur & $23005.307 ' \mathrm{~N}, 90038.882^{\prime} \mathrm{E}$ \\
7. & Chor Voirabi (CV), Chandpur & $23002.072^{\prime} \mathrm{N}, 90039.219^{\prime} \mathrm{E}$ \\
8. & Ishanbala (Ib), Chandpur & $23008.110^{\prime} \mathrm{N}, 90038.015^{\prime} \mathrm{E}$ \\
9. & Chor Jalalpur (CJ), Sariatpur & $23004.257^{\prime} \mathrm{N}, 90039.403^{\prime} \mathrm{E}$ \\
10. & Hizla (Hz), Barisal & $22053.941^{\prime} \mathrm{N}, 90031.984^{\prime} \mathrm{E}$ \\
11. & Kaliganj (Kg), Barisal & $22052.514^{\prime} \mathrm{N}, 90035.753^{\prime} \mathrm{E}$ \\
12. & Chor Ludhua (CL), Laxmipur & $22045.523^{\prime} \mathrm{N}, 90049.511^{\prime} \mathrm{E}$ \\
13. & Chor Alexandar (Axr), Laxmipur & $22041.275^{\prime} \mathrm{N}, 90050.348^{\prime} \mathrm{E}$ \\
\hline
\end{tabular}

\subsection{Sample collection}

Water samples were collected from the selected sampling spots (Table1). Surface water samples were collected from $15-30 \mathrm{~cm}$ below the river water surface and at distances of 40-80 $\mathrm{cm}$ from the bank of the river in labeled sample bottles that were washed with conc. $\mathrm{HNO}_{3}$ and rinsed repeatedly with distilled water. Before sample collection, sample bottles were rinsed three times also with the river water. Plankton samples were collected from each sampling sites normally at early morning by standard drop count method (APHA, 1995) during the study period. Replicate plankton samples were collected by means of a bucket (50litre) and filtered through bolting silk plankton net of $50 \mu$. The filtrate were transferred to $100 \mathrm{ml}$ plastic bottle and preserved immediately in 1:100 Lugol's solution. Counting and identification were done as per Ward and Whipple (1959) and Presecot (1962).

\subsection{Assessment of physicochemical properties}

Physicochemical water quality parameters such as water temperature $\left({ }^{0} \mathrm{C}\right)$, air temperature $\left({ }^{0} \mathrm{C}\right)$, Conductivity $(\mu \mathrm{s} / \mathrm{cm})$, transparency $(\mathrm{cm})$, dissolve oxygen $(\mathrm{mg} / \mathrm{l})$, free carbon dioxide $(\mathrm{mg} / \mathrm{l}), \mathrm{pH}$, total alkalinity $(\mathrm{mg} / \mathrm{l})$, total hardness $(\mathrm{mg} / \mathrm{l})$ and ammonia $(\mathrm{mg} / \mathrm{l})$ were analyzed on the same day of sampling. The transparency of the water was measured using $20 \mathrm{~cm}$ diameter Secchi disc, which was dipped into the water till the disk disappeared and 
the depth was recorded. A centigrade thermometer measured temperature of air and water. Free $\mathrm{CO}_{2}$ content was determined by phenolphthalein indicator method (Welch, 1948). Total alkalinity was estimated by using phenolphthalein and methyl orange indicator method (Welch, 1948). Total hardness was determined by EDTA titrimetric method (APHA, 1995). HACH water test kit (Model-FF-2, USA) was used to measure pH, dissolved oxygen (DO) and ammonia $\left(\mathrm{NH}_{3}\right)$. Conductivity was measured by EC meter (HANNA instruments: H19143).

\subsection{Statistical analysis}

MS Excel 2010 version was used to the analysis of data obtained, which include descriptive analyses. Likewise correlation was also utilized in the case of testing for any significant correlation between the variables.

\section{Results and Discussion}

The physicochemical parameters (Avg. \pm SD) values obtained from the thirteen (13) sites of the river Meghna were given in Table 2. Presence of phytoplankton and zooplankton were given in Tables 3, 4 and 5. Dominating groups of plankton and total counted plankton were shown in Table 3.

Table 2. Physicochemical properties of water in the selected sampling spots of the river Meghna.

\begin{tabular}{|c|c|c|c|c|c|c|c|c|c|c|}
\hline \multirow[t]{2}{*}{ Places } & \multicolumn{10}{|c|}{ Parameters } \\
\hline & $\begin{array}{l}\text { Air } \\
\text { Temp. } \\
\left({ }^{0} \mathrm{c}\right)\end{array}$ & $\begin{array}{l}\text { Water } \\
\text { Temp. } \\
\left({ }^{0} \text { c) }\right.\end{array}$ & $\begin{array}{l}\text { Tranper } \\
\text { ency } \\
(\mathrm{cm})\end{array}$ & $\begin{array}{l}\text { DO } \\
(\mathrm{mg} / \mathrm{l})\end{array}$ & $\begin{array}{l}\text { Free } \\
\mathrm{Co}_{2} \\
(\mathrm{mg} / \mathrm{l})\end{array}$ & pH & $\begin{array}{l}\text { T. } \\
\text { Hardness } \\
(\mathrm{mg} / \mathrm{l})\end{array}$ & $\begin{array}{l}\text { T. } \\
\text { Alkalinity } \\
\text { (mg/l) }\end{array}$ & $\begin{array}{l}\text { Conductivity } \\
(\mu \mathrm{s} / \mathrm{cm})\end{array}$ & $\begin{array}{l}\mathrm{NH}_{3} \\
(\mathrm{mg} / \mathrm{l})\end{array}$ \\
\hline MG & $15.6-37$ & $17.8-30$ & $25-59$ & $5.5-6.5$ & $8.4-10$ & $7.8-8.25$ & $60-68$ & $29-50$ & $148-280$ & $00-0.03$ \\
\hline $\mathbf{A B}$ & $21-37$ & $21.1-30$ & $26-50$ & $6.2-6.4$ & $10.4-16.5$ & $7.8-8.5$ & $46-88$ & $48-62$ & $163-281$ & 0.0 \\
\hline Ep & $22-26$ & $20-29$ & $16-66$ & $5.0-6.0$ & $8.0-13.4$ & $7.3-7.5$ & $35-67$ & $27-48$ & $141-263$ & 0.0 \\
\hline Sn & $18.9-25$ & $21.1-29$ & $38.3-62$ & $4.0-6.4$ & $5.6-13.8$ & $7.3-7.5$ & $36-69$ & $30-50$ & $137-268$ & 0.0 \\
\hline HG & $22.2-26$ & $19-24$ & $45-75$ & $7.2-7.3$ & $5.0-5.2$ & $7.5-8.3$ & $88-90$ & $41-45$ & $272-290$ & $0.02-0.03$ \\
\hline HC & $21-32$ & $18.9-29$ & $35-50$ & $5.3-5.7$ & $9.5-12$ & $7.8-8.0$ & $120-185$ & $130-132$ & $223-277$ & 0.0 \\
\hline $\mathrm{CV}$ & $16.7-32$ & $16.1-29.5$ & $33-56$ & $5.7-7.3$ & $12-17$ & $8.0-8.3$ & $102-124$ & $58-132$ & $211-275$ & 0.0 \\
\hline Ib & $20.3-30$ & $18.9-28.5$ & $20-41$ & $5.2-7.2$ & $8.8-15$ & $7.8-8.3$ & $96-121$ & $36-79$ & $218-282$ & 0.0 \\
\hline CJ & $21.1-32$ & $19.4-30.5$ & $21-40$ & $5.6-7.1$ & $8.6-15.1$ & $7.5-8.3$ & $94-120$ & $42-80$ & $214-288$ & 0.0 \\
\hline $\mathbf{H z}$ & $22.2-30$ & $21.1-28$ & $21-39$ & $5.2-7.1$ & $9.2-14$ & $8.0-9.0$ & $48-97$ & $29-71$ & 176-199 & 0.0 \\
\hline Kg & $22.2-30$ & $20.0-30$ & $19-30$ & $3.5-7.2$ & $15-17$ & $7.8-8.3$ & $85-103$ & $38-71$ & $174-279$ & 0.0 \\
\hline CL & $21.1-32$ & $18.9-30$ & $12-27$ & $4.5-6.8$ & $11.4-13$ & $8.0-8.5$ & $115-403$ & $54-137$ & $400-1000$ & 0.0 \\
\hline $\mathbf{A x r}$ & $18.9-30$ & $19-30$ & $15-41$ & $3.7-6.5$ & $13.0-14$ & $8.0-8.2$ & $417-802$ & $100-145$ & $370-1000$ & 0.0 \\
\hline $\begin{array}{l}\text { Mean } \pm \\
\text { SD }\end{array}$ & $1.4 \pm 24.8$ & $1.4 \pm 23.7$ & $9.4 \pm 36.3$ & $0.6 \pm 5.9$ & $2.6 \pm 11.3$ & $0.3 \pm 7.9$ & $151 \pm 141.5$ & $32.2 \pm 67.9$ & $175.6 \pm 301.1$ & $\begin{array}{l}0.008 \pm \\
0.003\end{array}$ \\
\hline
\end{tabular}

\subsection{Physical properties}

\subsubsection{Air and water temperature}

Water temperature is an important factor in any aquatic environment affecting biological processes. Temperature is a common indicator to assess the physical condition of water quality. Temperature impacts both the chemical and biological characteristics of surface. From the recorded results the minimum and maximum temperature were shown a great variation from upstream to downstream. High and low seasonal variations were observed at all the sites. Water temperature was high due to low water level, high air temperature and clean atmosphere. Maximum air temperature was recorded $37^{\circ} \mathrm{C}$ at Ananda Bazar and minimum at $15.6^{\circ} \mathrm{C}$ at Madrasa Ghat area. Maximum water temperature was recorded $30^{\circ} \mathrm{C}$ at Kaligonj, Chor Ludhua and Chor Alexander area of the river Meghna and minimum value was recorded from Chor voirabi area (Table 2). The surface water temperature of the river was found always lower than air temperature. The marked variation and significant differences in physicochemical properties of the water indicate the different environmental conditions.

\subsubsection{Transparency}

In the present study, transparency was found minimum $12 \mathrm{~cm}$ at Chor Ludhua and maximum $75 \mathrm{~cm}$ at Horina Ghat with a mean of $36.27 \pm 9.40$ at different sampling stations (Table 2). The transparency of water was found higher at the low tidal stretch of the river. Almost slide mixing muddy water was found in around the estuarine region. Khan and Chowdhury (1994) reported that higher transparency occur during winter and summer due to absence of rain, runoff and flood water as well as gradual settling of suspended particles. 


\subsection{Chemical properties}

\subsubsection{Dissolved oxygen (DO)}

Dissolve oxygen is the sole source of oxygen for all the aerobic aquatic life and hence it is considered as an important measure of purity for all waters. It reflects the water quality status and physical and biological processes in waters and shows the metabolic balance of a river system. Dissolve oxygen is an important water quality parameter in assessing water pollution (Laluraj et al., 2002). In the present study, the concentration of dissolved oxygen was found maximum at Chor Voirabi and Horina Ghat $7.3 \mathrm{mg} / \mathrm{l}$ and was found minimum at Kaligonj $3.5 \mathrm{mg} / \mathrm{l}$ with a mean of $5.92 \pm 0.61 \mathrm{mg} / \mathrm{l}$ (Table 2). Dissolved oxygen content was found gradually decreasing from the upper to lower stretches of the river system (Table 2). Rani et al. (2004) also reported lower values of dissolved oxygen in summer season due to higher rate of decomposition of organic matter and limited flow of water in low holding environment due to high temperature. The cause of maximum dissolve oxygen in winter months may be due to the reduced rate of decomposition by decreased microbial activity at low temperature (Prasad and Singh, 2003).

\subsubsection{Free carbon dioxide (Free $\left.\mathrm{Co}_{2}\right)$}

Free $\mathrm{CO}_{2}$ was found highest at Kaligonj $17 \mathrm{mg} / \mathrm{l}$ and lowest at Horina Ghat $5 \mathrm{mg} / \mathrm{l}$ (Table 2). Free $\mathrm{Co}_{2}$ content was found gradually decreasing from the upper to lower stretches of the river system. The rise in temperature in the river water could be correlated with increase in carbon dioxide levels (Talling, 1957) when the water level decreased sharply during summer.

\subsection{3. $\mathrm{pH}$}

$\mathrm{pH}$ can affect the aquatic life indirectly by altering other aspects of water chemistry e.g. low pH levels can increase the solubility of certain heavy metals. In the present study, $\mathrm{pH}$ was found ranged from neutral to alkaline (Minimum 7.2 to Maximum 9) at different stations with a mean $7.94 \pm 0.3$ (Table 2). During the entire period of study $\mathrm{pH}$ of surface water was found mostly alkaline in nature. The high values may be due to attributed pollution by water flow and circulation. Fluctuations in $\mathrm{pH}$ values during different season of the year were attributed to factors like removal of $\mathrm{CO}_{2}$ by photosynthesis through bicarbonate degradation, dilution of waste with fresh water, reduction in salinity and temperature, and decomposition of organic matter (Rajasegar, 2003). According to (Chisty, 2002) $\mathrm{pH}$ value is very important for plankton growth. Marathi et al. (2007) reported $\mathrm{pH}$ is ranged 5 to 8.5 is best for plankton growth.

\subsubsection{Total hardness}

Hardness is important to aquaculture. Hardness of water influenced by the most common sources like as calcium and magnesium and calcium and magnesium are essential in the biological processes of aquatic animals, especially for bone and scale formation in fish (Wurts and Durborow, 1992). In the present study, total hardness was found highest at Chor Alexander $802 \mathrm{mg} / \mathrm{l}$ and lowest at Eklaspur $35 \mathrm{mg} / \mathrm{l}$ in different sampling locations (Table 2). High values may be due to the addition of calcium and magnesium salts in river water. The increase in hardness can be attributed to the decrease in water volume and increase in the rate of evaporation at high temperature. Hujare (2008) reported total hardness was higher in summer than rainy season and winter season.

\subsubsection{Total alkalinity}

Alkalinity of water is its capacity to neutralize a strong acid and is characterized by presence of all hydroxyl ions capable of combining with hydrogen ions (Koshy and Nayar, 2000). Total alkalinity was found highest at Chor Alexander $145 \mathrm{mg} / \mathrm{l}$ and found minimum at Madrasa Ghat and Hizla $29 \mathrm{mg} / \mathrm{l}$ (Table 2). Bhuiyan (1970) recorded the total alkalinity of medium productive water body ranging from 25 to $100 \mathrm{mg} / \mathrm{l}$. Buffering capacity of rivers depends on alkalinity whereas alkalinity is measured to determine the ability of river to resist changes in $\mathrm{pH}$.

\subsubsection{Conductivity}

Conductivity has a relationship with transparency. When conductivity showed an increasing trend then transparency showed a decreasing trend. Conductivity was found highest at Alexander and Chor Ludhua 1000 $\mu \mathrm{s} / \mathrm{cm}$ and was found minimum at Eklaspur $141 \mu \mathrm{s} / \mathrm{cm}$ (Table 2). Increasing levels of conductivity and cations are the products of decomposition and mineralization of organic materials (Abida, 2008). 


\subsubsection{Ammonia}

During the study period, ammonia concentration was found ranged from 0.00 to $0.03 \mathrm{mg} / \mathrm{l}$. Maximum value was recorded from Horina Ghat (Table 2). These values indicate till date ammonia concentrations in the selected sampling spots remain in the suitable range. These values are much lower than the Chisty (2002) and Rani et al. (2004).

\subsection{Plankton composition}

Abundance and quantity of plankton of both phytoplankton and zooplankton in 13 sampling stations of the river Meghna has been presented in Tables 3, 4 and 5.

Table 3. Mean quantitative values of plankton with dominating genera in selected sampling points of the river Meghna.

\begin{tabular}{|c|c|c|c|c|c|c|}
\hline Places & $\begin{array}{l}\text { Total Phyto. } \\
\text { (No./l) }\end{array}$ & $\begin{array}{l}\text { Dominating Phyto. } \\
\text { (No./l) }\end{array}$ & $\begin{array}{l}\text { Other Phyto. } \\
\text { (No./I) }\end{array}$ & $\begin{array}{l}\text { Total Zoo. } \\
\text { (No./I) }\end{array}$ & Dominating Zoo. (No./I) & $\begin{array}{l}\text { Other Zoo. } \\
\text { (No./I) }\end{array}$ \\
\hline MG & $146 \times 10^{2}$ & Ulothrix $\left(91 \times 10^{2}\right)$ & $55 \times 10^{2}$ & $33 \times 10^{2}$ & Brachionus $\left(25 \times 10^{2}\right)$ & $8 \times 10^{2}$ \\
\hline $\mathrm{AB}$ & $59 \times 10^{2}$ & Ulothrix $\left(19 \times 10^{2}\right)$ & $40 \times 10^{2}$ & $12 \times 10^{2}$ & Brachionus $\left(10 \times 10^{2}\right)$ & $2 \times 10^{2}$ \\
\hline EP & $256 \times 10^{2}$ & Melosera $\left(105 \times 10^{2}\right)$ & $151 \times 10^{2}$ & $4 \times 10^{2}$ & Nauplius $\quad\left(3 \times 10^{2}\right)$ & $1 \times 10^{2}$ \\
\hline $\mathrm{Sn}$ & $29 \times 10^{2}$ & Ulothrix $\left(17 \times 10^{2}\right)$ & $12 \times 10^{2}$ & $8 \times 10^{2}$ & Brachionus $\left(5 \times 10^{2}\right)$ & $3 \times 10^{2}$ \\
\hline HG & $410 \times 10^{2}$ & Ulothrix $\left(183 \times 10^{2}\right)$ & $227 \times 10^{2}$ & $26 \times 10^{2}$ & Brachionus $\left(19 \times 10^{2}\right)$ & $7 \times 10^{2}$ \\
\hline $\mathrm{HC}$ & $267 \times 10^{2}$ & Ulothrix $\left(193 \times 10^{2}\right)$ & $74 \times 10^{2}$ & $18 \times 10^{2}$ & Brachionus $\left(14 \times 10^{2}\right)$ & $4 \times 10^{2}$ \\
\hline $\mathrm{CV}$ & $305 \times 10^{2}$ & Ulothrix $\left(235 \times 10^{2}\right)$ & $70 \times 10^{2}$ & $13 \times 10^{2}$ & Brachionus $\left(9 \times 10^{2}\right)$ & $4 \times 10^{2}$ \\
\hline $\mathrm{Ib}$ & $293 \times 10^{2}$ & Ulothrix $\left(185 \times 10^{2}\right)$ & $108 \times 10^{2}$ & $30 \times 10^{2}$ & Brachionus $\left(22 \times 10^{2}\right)$ & $8 \times 10^{2}$ \\
\hline CJ & $239 \times 10^{2}$ & Ulothrix $\left(98 \times 10^{2}\right)$ & $141 \times 10^{2}$ & $35 \times 10^{2}$ & Brachionus $\left(20 \times 10^{2}\right)$ & $15 \times 10^{2}$ \\
\hline $\mathrm{HZ}$ & $443 \times 10^{2}$ & Ulothrix $\left(305 \times 10^{2}\right)$ & $138 \times 10^{2}$ & $27 \times 10^{2}$ & Brachionus $\left(20 \times 10^{2}\right)$ & $7 \times 10^{2}$ \\
\hline KG & $389 \times 10^{2}$ & Ulothrix $\left(278 \times 10^{2}\right)$ & $111 \times 10^{2}$ & $26 \times 10^{2}$ & Brachionus $\left(17 \times 10^{2}\right)$ & $9 \times 10^{2}$ \\
\hline CL & $230 \times 10^{2}$ & Ulothrix $\left(169 \times 10^{2}\right)$ & $61 \times 10^{2}$ & $11 \times 10^{2}$ & Brachionus $\left(8 \times 10^{2}\right)$ & $3 \times 10^{2}$ \\
\hline Axr & $196 \times 10^{2}$ & Ulothrix $\left(112 \times 10^{2}\right)$ & $84 \times 10^{2}$ & $6 \times 10^{2}$ & Nauplius $\quad\left(3 \times 10^{2}\right)$ & $3 \times 10^{2}$ \\
\hline Total & $3252 \times 10^{2}$ & $1990 \times 10^{2}$ & $1272 \times 10^{2}$ & $249 \times 10^{2}$ & $175 \times 10^{2}$ & $74 \times 10^{2}$ \\
\hline
\end{tabular}

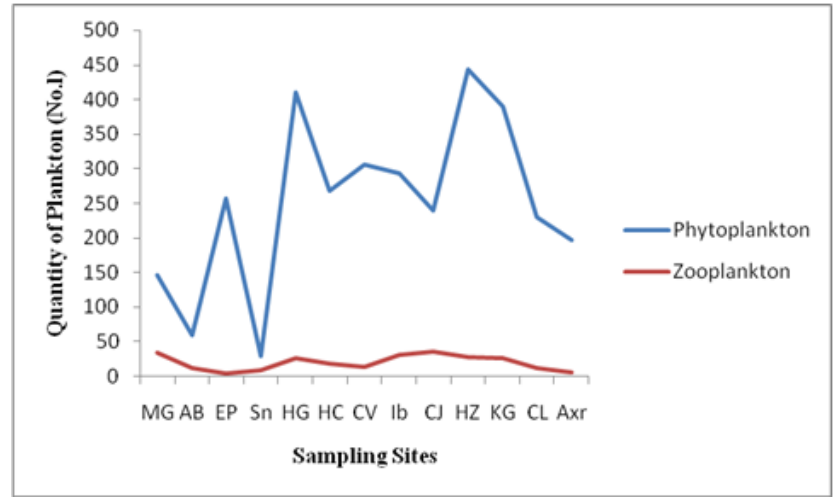

Figure 1. Plankton composition of the river Meghna (Shatnol to Chor Alexandar).

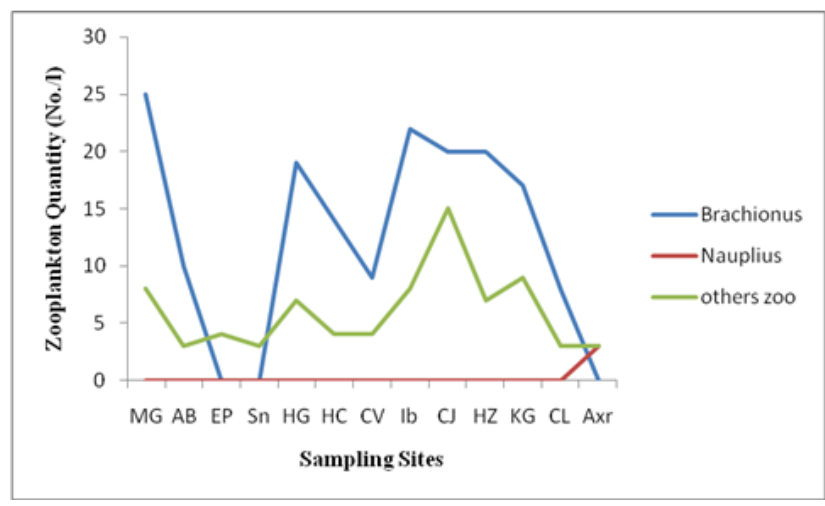

Figure 2. Zooplankton composition of the river Meghna (Shatnol to Chor Alexandar). 


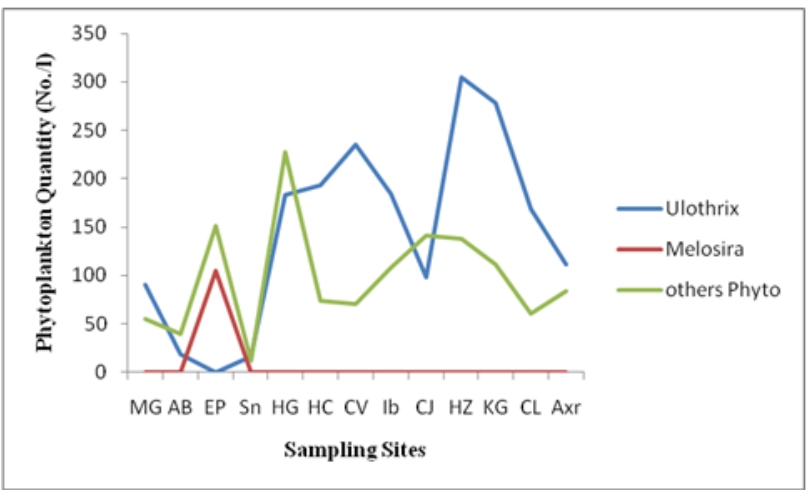

Figure 3. Phytoplankton composition of the river Meghna (Shatnol to Chor Alexandar).

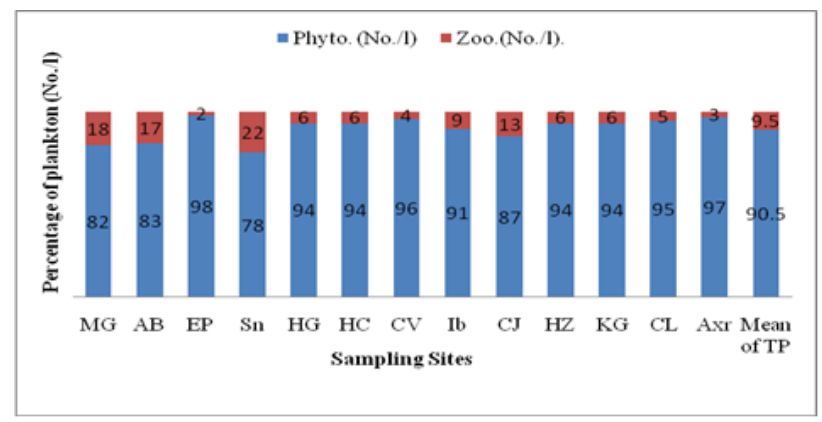

TP=Total Plankton

Figure 4. Percent (\%) composition of phytoplankton and zooplankton in the river Meghna (Shatnol to Chor Alexandar).

Table 4. Phytoplankton families with genus composition were observed during the study period.

\begin{tabular}{|c|c|c|}
\hline SL No. & Family & Genus \\
\hline 1. & Cholorophyceae & $\begin{array}{l}\text { Ankistrodesmus, Eudorina, Crucigenia, Chlamydomonas, Ceratium, Closterium, } \\
\text { Gonatozygon, Microspora, Genecularia, Pleodarina, Spirogyra, Scenedesmus, } \\
\text { Mougeotia, Volvox, Zygenema, Pediastrum }\end{array}$ \\
\hline 2. & Dinophyceae & Ulothrix, Protoccocus \\
\hline 3. & Bacillariophyceae & $\begin{array}{l}\text { Amphora, Tabellaria, Coscinodesmus, Cyclotella, Ditoma, Fragilaria, Melosira, } \\
\text { Navicula, Nitzchia, Polycistis, Stphanodesmus, Synedra, Asterionella }\end{array}$ \\
\hline 4. & Cyano & Spirulina, Scenedesmus \\
\hline 5. & Myxophyceae & Tetrapedia, Coelosphaerium, Merismopedia, Oedogonium, Aphanocapsa \\
\hline 6. & Euglenophyceae & Tribonema \\
\hline 7. & Xanthophyceae & Trachelomonus, Euglena \\
\hline
\end{tabular}

Table 5. Zooplankton families with genus composition were observed during the study period.

\begin{tabular}{lll}
\hline SL No. & Family & Genus \\
\hline 1. & Rotifers & Trichocera, Brachionu \\
2. & Copepods & Nauplius, Diaptomus, Cyclops \\
3. & Cladocera & Daphia, Diaphanosoma, Chydorus \\
4. & Ostracods & Cypris \\
\hline
\end{tabular}

\subsubsection{Phytoplankton}

During the study period, 41 genera belongs to Bacillariophyceae with 13 genera, Chlorophyceae with 15 genera, Cyanophyceae with 3 genera, Dinophyceae with 2 genera, Euglenophyceae with 1 genus, Myxophyceae with 5 genera and Xanthophyceae with 2 genera were recorded (Table 4). In the river Meghna, phytoplanktons were dominated largely over zooplanktons (Figure 1). The mean contribution of phytoplankton was about $90.5 \%$ of the total planktonic organisms and zooplankton contributed the rest (Figure 4). Shafi et al. (1978) reported that higher percentage of phytoplankton 76.0 to $93.6 \%$ from the same ecosystem. Sundar et al. (1995) also reported 
that the major contribution of phytoplankton (> 97.0\%) and lower concentration of zooplankton 0.13 to $2.4 \%$ at three stations in the Guala river of Uttar Pradesh, India. Higher phytoplankton concentrations in water normally indicate higher productivity. In the present study, total phytoplankton population $\left(3252 \times 10^{2}\right)$ was dominated by Dinophyceae (Ulothrix $\left.1885 \times 10^{2}\right)$, secondly Bacillariophyceae (Melosira $\left.105 \times 10^{2}\right)$ and rest of $\left(1262 \times 10^{2}\right)$ followed by Chlorophyceae, Cyanophyceae, Euglenophyceae, Myxophyceae, Xanthophyceae respectively (Figure 3).

\subsubsection{Zooplankton}

During the present investigation, total 9 genera of zooplanktons were found with four families namely Rotifera with 2 genera, Cladocera with 3 genera, Copepoda with 3 genera and Ostracoda with 1 genus were identified from the selected sampling spots (Table 5). Zooplankton was found more than 9\% in the total planktonic organisms. Shafi et al. (1978) and Sundar et al. (1995) reported the almost same observation in their investigations. Ahmed et al., (2003) also found that zooplankton contributed more than 3\% in the total planktonic organisms. Creating factors such as light intensity, food availability, dissolved oxygen and predation affect the population dynamics of zooplankton. In this study, the zooplankton diversity was recorded in the following order, Rotifera>Copepoda>Cladocera>Ostracoda (Table 5). During the present investigation, presence of copepod with 3 genera and Cladocera with 3 genera were the most dominant groups in the study area of the Meghna River (Table 5).

Total zooplankton population $\left(175 \times 10^{2}\right)$ was dominated by Rotifera (Brachionus $\left.169 \times 10^{2}\right)$, Copepods $\left(6 \times 10^{2}\right)$ and rest of $\left(74 \times 10^{2}\right)$ followed by others (Table 3). A single genus of zooplankton namely Brachionus of specific group was found as a regular component for almost all sampling stations (Figure 2). However in the river Meghna, presence of zooplankton was found highest at Kaligonj and Eklaspur with 6 genera and lowest at Shatnol and Chor Ludhua with 2 genera (Table 5).

\section{Conclusions}

The present study concluded that physicochemical and planktonic characteristics of all the thirteen sites of the river Meghna showed wide range of variation. Higher presence of phytoplankton in the river Meghna indicates good physicochemical conditions and good water quality to a much extent showed less effect of pollution load. The physicochemical conditions of the river Meghna is good and provide a healthier environment for the growth and survival of fishes as well as biological communities. But it does not mean that the river is free from pollution and it is important to monitor regularly. Mainly management efforts should be made for the conservation approach and sustainable run of the river Meghna otherwise it will pollute rapidly and perhaps might be turn into the deadly condition after a certain period.

\section{Conflict of interest}

None to declare.

\section{References}

Abida B and Harikrisna, 2008. Study on the quality of water in some streams of Cauvery river. E- Journal of Chemistry, 5:377-384.

Ahmed KKU, SU Ahmed, MRA Hossain, T Ahmed, and S Rahman, 2003. Quantitative and qualitative assessment of plankton: some ecological aspect and water quality parameters of the river Meghna, Bangladesh. Bangladesh J. Fish Res., 7: 131-140.

APHA (American Public Health Association) 1995. Standard methods for the examination of water and waste water. 14th Ed., American Public Health Association. 1015 Eighteenth Street, N. W. Washington, D. C. 2036.

Chisty N, 2002. Studies on biodiversity of freshwater zooplankton in relation to toxicity of selected heavy metals. Ph. D. Thesis submitted to M.L Sukhadia Univeristy Udaipur.

Hambright KD and T Zohary, 2000. Phytoplankton species diversity control through competitive exclusion and physical disturbances. Limnol. Oceanogr., 45: 110-122.

Haroon AKY, 1998. Hilsa shad: Fish for the teeming millions, new management alternatives needed for the hilsa young. Shad Journal., 3:1-12.

Hujare MS, 2008. Seasonal variation of physicochemical parameters in the perennial tank of Talsande, Maharashtra. Ecotox. and Environ. Monitor., 18:233-242.

Khan MAG and SH Choudhary, 1994. Physical and chemical limnology of lake Kaptai: Bangladesh, Tropical Ecol., 35:35-51. 
Khanna DR and F Ishaq, 2012. Analysis of Heavy Metals and their interrelationship with some water quality parameters of River Yamuna in Dehradun Uttarakhand. Biochem. Cell. Arch., 12: 273-280.

Koshy M and TV Nayar, 1999. Water quality aspects of river pamba. Pollut. Res., 18:501- 510.

Laluraj CM, P Padma, CH Sujatha, SM Nair, NC Kumar and J Chacko, 2002. Base-line studies on the chemical constitutes of Kayamkulam estuary near to the newly commissioned NTPC power station. Indian J. of Environ. Protec., 22:721-731.

Odum EP, 1971. Fundamentals of Ecology. 3rd edn. WB Saunders Co., Phil, USA, p. 574.

Peerapornpisal Y, W Sonthichai, T Somdee, P Mulsin and E Rott 1999. Water quality and phytoplankton in the Mae Kuang Udomtara Reservoir, Chiang Mai, Thailand. J. Sci. Fac. Cmu., 26:25-43.

Presecot GW, 1962. Algae of the Western Great Lakes Area. Revised. Ed W. M. C. Brown Company, 135 South locust streets, Dubuque, Lowa, 977pp.

Prasad BB and RB Singh 2003. Composition, abundance and distribution of phytoplankton and zoobenthos in a tropical water body. Nat. Envin. Pollut. Technol., 2: 255-258.

Rajasegar M, 2003. Physico-chemical characteristics of the Vellar estuary in relation to shrimp farming. J. Environ. Biol., 24:95-101.

Rani R, BK Gupta and KBL Srivastava, 2004. Studies on water quality assessment in Satna city (M.P): Seasonal parametric variations, Nature environment and pollution technology, 3:563-565.

Shafi M, MMA Quddus, and N Islam, 1978. Studies on the limnology of the river Meghna. Bangladesh J. Fish. 1:85-97.

Sundar S, HS Raina, M Mohon, and B Singh 1995. Ecology and fiheries potentials of the Guala river with special reference to proposed impoundment (Jamrani dam) on the system. Inland Fish. Soc. India 27:33-45.

Talling JF, 1957. The longitudinal succession ofthe water characteristics in White Nile. Hydrobiologia. 90:7389.

Umavathi S, K Longakumar, and Subhashini, 2007. Studies on the nutrient content of Sulur pond in Coimbator, Tamil Nadu, Journal of ecol. and environ. conser., 13: 501-504.

UN (United Nations) 1995. Guidebook to water resources, use and management in Asia and the Pacific. Volume one: Water resources and water use. Water resources series, No. 74: 20-29.

Ward HB and GC Whipple, 1959. Freshwater Biology (2nd ed.), John Wiley and Sons, Incorporated, New York, 1248p.

Welch SP, 1948. Limnological methods. McGraw Hill Book Co., New York, USA, 381.

Wurts WA and RM Durborow 1992. Interactions of pH, carbon dioxide, alkalinity and hardness in fish ponds. Southern Regional Aquaculture Center, Publication No. 464. 